
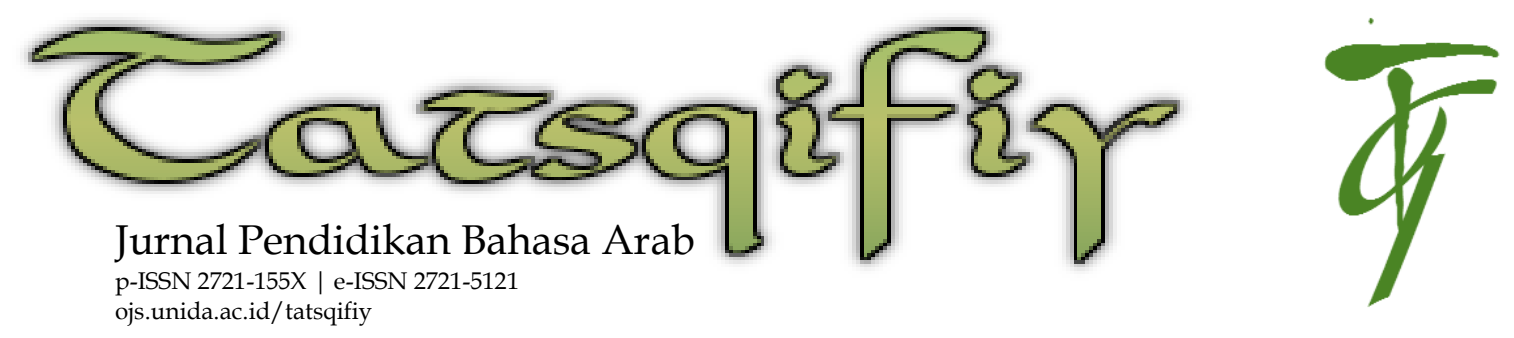

\title{
Ikhtilaf Al-I'rab dalam Al-Qur'an Surah Al-Insan dan Implikasinya dalam Pembelajaran Nahwu di Madrasah Tsanawiyah
}

\author{
Muhammad Mu'min \\ Pendidikan Bahasa Arab, Fakultas Keguruan dan Ilmu Pendidikan \\ Universitas Djuanda \\ Jl. Tol Ciawi, Kotak pos 35 Bogor 1672 Telp. (0251) 8240773 Fax 8240985
}

Volume 2 Nomor 1

Januari 2021: 1-23

DOI: $10.30997 /$ tjpba.v2i1.3630

Article History

Submission: 04-11-2020

Revised: 05-12-2020

Accepted: 01-01-2021

Published: 26-01-2021

Kata Kunci:

Analisis, Ikhtilafi'rab, Pembelajaran Nahwu

Keywords:

Analysis, Ikhtilafi'rab, Nahwu Learning

Korespondensi:

Muhammad Mu'min

Telp. 085773359362

syababulquran@gmail.com

\begin{abstract}
Abstrak: Penelitian ini dilatarbelakangi oleh pengalaman dan pengamatan peneliti akan minimnya penggunaan ayat-ayat Al-Qur'an sebagai bahan ajar pada pembelajaran nahwu di Madrasah Tsanawiyah, selain itu masih banyak pelajar muslim pada khususnya yang masih kesulitan dalam mengi'rab kalimat-kalimat bahasa Arab, sehingga penelitian mengenai ikhtilaf i'rab ini sangat penting karena berguna untuk menghindarkan kita dari kesalahan dalam memahami Al-Qur'an maupun teks-teks Arab lainnya. Tujuan penelitian ini adalah untuk mengetahui aspek-aspek ikhtilaf $i^{\prime} r a b$ dalam surah $\mathrm{Al}$ Insan, sehingga dapat diketahui faktor-faktor penyebab perbedaannya dan pengaruhnya terhadap makna. Dalam melakukan penelitian ini peneliti menggunakan pendekatan kualitatif, yaitu suatu penelitian yang dilakukan berdasarkan paradigma, strategi, dan implementasi model secara kualitatif, adapun metode penelitian yang digunakan adalah metode deskriptif analitik, yaitu suatu metode yang digunakan untuk menemukan dan mengungkapkan permasalahan sistematis, dengan cara mendeskripsikan data-data yang kemudian disusul dengan analisis. Dalam penelitian ini, peneliti berusaha menganalisa objek penelitian untuk digambarkan sebagaimana adanya. Berdasarkan hasil analisis pada penelitian ini bahwa dalam surah AlInsan ini terdapat 10 kata yang mengandung ikhtilaf $i^{\prime} r a b$ didalamnya, 8 kata disebabkan karena aspek bahasa dan 2 kata disebabkan karena aspek qiraat alqur'an.
\end{abstract}


Ikhtilaf Al-I'rab in Al-Qur'an Surah Al-Insan and its implications in Nahwu Learning in Islamic Junior High School

Abstract: This research is motivated by the experience and observation of researchers the lack of use of the verses of the Qur'an as teaching material in learning nahwu in a Junior High School, besides that there are still many Muslim students in particular who still have difficulty in i'rab Arabic sentences, so research on this ikhtilaf i'rab is very important because it is useful to prevent us from misunderstanding the Qur'an and other Arabic texts. The purpose of this research is to find out the aspects of the ikhtilafi'rab in Surah Al-Insan, so that it can be known the factors that cause the differences and their effects on meaning. The approach used in this study is a qualitative approach, which is a study conducted based on paradigms, strategies, and qualitative model implementation, while the research method used is descriptive analytic method, which is a method used to find and express systematic problems, by means of describe the data which is then followed by analysis. In this study, researchers tried to analyze the research object to be described as is. Based on the results of the analysis in this study that in Surah Al-Insan there are 10 words that contain the ikhtilaf i'rab in it, 8 words are caused by aspects of language and 2 words are caused by aspects of qiraat al-qur'an.

\section{PENDAHULUAN}

Salah satu alat komunikasi yang sering digunakan oleh manusia adalah bahasa, sehingga bahasa berperan penting dalam kehidupan manusia, dengan bahasa seorang guru menyampaikan ilmunya, mengabadikannya karya tulisnya, bertukar pikiran dan lain sebagainya. Sebagaimana penjelasan Abdul Chaer bahwa "Bahasa sebagai media komunikasi sangat diperlukan oleh manusia untuk mengemukakan gagasan, pikiran, konsep dan perasaan"(Agustina, 2009).

\section{Bahasa Arab adalah bahasa} komunikasi dalam Al-Qur'an. Sebagai bahasa kitab suci Al-Qur'an, bahasa Arab tidak bisa dipisahkan dari umat Islam. Karena itu, dengan semangat untuk mengkaji dan memperdalam ajaran Islam melalui kitab-kitab berbahasa arab, pembelajaran bahasa arab dipondok-pondok pesantren di Indonesia mulai dilaksanakan (Hamid, 2012).

Selain itu, bahasa Arab juga merupakan bahasa persatuan umat Islam dan bahasa Al-Qur'an serta Hadis 
yang merupakan rujukan utama umat islam, dengan bahasa tersebut umat Islam beribadah, berkomunikasi dan menuliskan karya-karya ilmiahnya.

Seperti yang diungkapkan oleh Syaikh Musthofa Al-Ghalayini bahwa bahasa Arab adalah kata yang diucapkan oleh orang Arab untuk mengungkapkan maksud mereka yang disampaikan dengan cara riwayat dan bahasa Arab dijaga oleh Al-Qur'an dan Hadis (Al-Ghalayini, 2010).

Keterampilan mendengar, membaca, menulis dan berbicara merupakan keterampilan pokok yang harus dipelajari ketika mempelajari bahasa asing, terkhusus ketika mempelajari bahasa Arab. Selain menguasai empat keterampilan pokok tersebut keterampilan selanjutnya yang tidak kalah penting adalah penguasaan gramatikal (nahwu). Ibnu Khaldun berpandangan, diantara empat cabang ilmu yang menjadi pilar bahasa, yaitu Bayan, Sastra, Lughah dan Nahwu, yang paling integral kedudukannya sebagai pilar dari linguistik Arab adalah ilmu Nahwu (Khaldun, 2006).

Pada dasarnya, ilmu Nahwu ini dibentuk dengan sangat praktis dan cukup sederhana. Dengan tujuan meluruskan kesalahan berbahasa dan menjaga kesalahan dalam membaca AlQur'an, ilmu Nahwu mulai dibentuk dengan sangat serius (Khaldun, 2006).

Kesalahan dalam berbahasa tersebut disebut dengan lahn. Lahn adalah istilah yang dipakai oleh bangsa Arab untuk menyebut kekeliruankekeliruan dalam berbahasa, sehingga ketika disebut kata lahn berarti bahasa tersebut memiliki kekeliruan dan sudah tidak fasih lagi.

Perhatian umat Islam di Indonesia terhadap bahasa Arab bisa dikatakan kurang jika dibandingkan dengan perhatiannya terhadap bahasa lain seperti bahasa inggris. Hal tersebut bisa kita lihat dari maraknya tempat-tempat kursus bahasa Inggris di berbagai daerah sedangkan tempat kursus bahasa Arab sangat jarang dijumpai, kemudian di Universitas Djuanda Bogor terdapat jurusan Pendidikan Bahasa Arab, akan tetapi sedikit sekali mahasiswa yang masuk ke dalam jurusan tersebut, angkatan pertama berjumlah 7 orang mahasiswa dan angkatan kedua berjumlah 7 orang pula, sungguh sangat sedikit sekali jika 

I" Muhammad Mu'min Ikhtilaf Al-I'rab dalam Al-Qur'an Surat Al-Insan ...

dibandingkan dengan jurusan-jurusan yang lain.

Kondisi ini sungguh sangat memprihatinkan, padahal bahasa Arab lah yang seharusnya mendapatkan perhatian khusus dikalangan umat Islam, karena dengan mengetahui bahasa Arab akan mengantarkan kita kepada pemahaman yang benar terhadap sumber-sumber pengetahuan Islam, sebaliknya tanpa pemahaman terhadap bahasa arab dapat dipastikan pemahamannya terhadap islam sangat diragukan.

Sayyid Ahmad Zaini Dahlan dalam kitabnya Mukhtasar Jiddan mengutip perkataan Imam Jalaluddin As-Suyuthi dalam kitab syarah Alfiyyahnya:

وقد اتفق العلماء على أن النحو يحتاج إليه في كل فن من فنون العلم لا سيما التفسير و الحديث، فإنه لا يجوز لأحد أن يتكلم في كتاب الله حتى يكون مليا بالعربية، لأن القرآن عربي و لا تفهم مقاصده إلا بمعرفة قو اعد

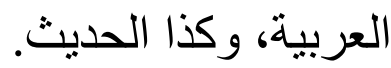

Artinya : "Ulama telah sepakat bahwa ilmu nahwu sangat dibutuhkan dalam setiap cabang ilmu terkhusus Al-Qur'an dan Hadis, sehingga haram menafsirkan Al-
Qur'an dan Hadits bagi seseorang yang tidak paham bahasa Arab, karena Al-Qur'an dan Hadis berbahasa Arab sehingga tidak mungkin seseorang bisa memahami AlQur'an dan Hadits tanpa memahami kaidah-kaidah bahasa Arab" (Dahlan, 2015).

Ilmu Bahasa Arab adalah Ilmu yang bisa menjaga kita dari kesalahan pengucapan dan penulisan. Adapun terkait cabang-cabang ilmu dalam Bahasa arab Syekh Musthafa AlGhalayini menyebutkan ada 13 cabang ilmu, yaitu Sharaf, I'rab, rasm, Ma'ani, Bayan, Badi', 'Arudh, Qowafi, Qordussyi'ir, Insya, Khitobah, Tarikh Adab dan Matan Lughah (Al-Ghalayini, 2010).

Dari semua cabang-cabang Ilmu bahasa Arab tersebut kebanyakan pelajar merasa kesulitan ketika Mengi'rab kalimat-kalimat Bahasa Arab, Sehingga hal ini mengundang perhatian ulama untuk menulis kitab yang berkaitan dengan I'rab.

I'rab adalah perubahan keadaan akhir kata yang disebabkan oleh masuknya 'amil yang berbeda-beda (Dahlan, 2015). Sedangkan Syeikh Musthafa al-Ghalayini menyatakan: 
أثر يحدثه العامل في آخر الكلمة فيكون آخر ها مرفوعا أومنصوبا أو مجرورا أو أو الو

مجزوما حسب ما يقتضيه ذلك العام

Artinya: "Pengaruh yang ditimbulkan oleh 'amil pada akhir sebuah kata, sehingga ia berubah menjadi marfu', manșub, majrur, atau majzum sesuai apa yang dituntut oleh 'amil tersebut"(Al-Ghalayini, 2010).

I'rab terbagi kepada 4 bagian yaitu Rafa', Nashab, Jar dan Jazm. Rafa, Nashab dan Jar khusus untuk kalimah Isim dan terlarang pada kalimah Isim untuk menerima I'rab Jazm, sedangkan Rafa, Nashab dan Jazm khusus untuk kalimah Fi'il, dan terlarang pada fi'il I'rab Khofad/Jazm (An'im, 2016).

Tidak dipungkiri memang terkadang terjadi perbedaan I'rab dikalangan para ulama ketika mengi'rab kalimat-kalimat bahasa Arab terkhusus ketika mengi'rab Al-Qur'an. Contohnya : Firman Allah SWT dalam surat Al-Insan ayat 2 :
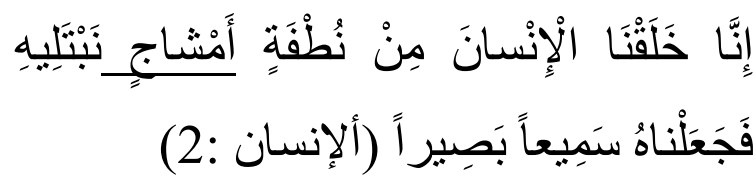

Artinya : "Sesungguhnya Kami (Allah) telah menciptakan insan dari setetes air mani yang bercampur, yang Kami hendak mengujinya (dengan melaksanakan perintah dan meninggalkan larangan). Oleh Karena itu, kami (Allah) jadikan dia mendengar dan melihat." (QS. Al-Insan : 2)

Pada Kata (أمشاج)) terdapat 2 perbedaan $i^{\prime} r a b$ :

a. Menyatakan bahwa kata أمشاج نطفة adalah sebagai Badal dari

b. Menyatakan bahwa kata أمشاج adalah Sifat/Na'at dari نطفة

Perbedaan tersebut disebabkan oleh beberapa faktor diantaranya aspek dalalah nahwiyah dan aspek qiraat alQur'an.

Untuk dapat memahami bahasa Arab dengan baik secara lisan dan tulisan, dibutuhkan suatu ilmu yaitu ilmu alat. Ilmu alat dalam bahasa Arab dikenal dengan istilah 'ulum al-lughah al'arabiyyah. Seperti 'ilmu shorof, 'ilmu nahwu, dan ilmu balaghah. Ilmu bahasa Arab sebagai alat bagi umat Islam untuk memperdalam ilmu agama merupakan suatu hal yang bersifat primer yang tidak bisa ditawar-tawar. Yang selanjutnya akan memudahkan mereka menghayati nilai-nilai agamanya serta mengamalkannya dalam kehidupan.

Adapun hukum mempelajari ilmu nahwu adalah fardu kifayah. Namun, 
boleh jadi ilmu ini menjadi wajib 'ain bagi kaum tertentu. Ilmu nahwu pula bertujuan untuk menjaga kesalahan lisan dalam mengucapkan kalam Arab, serta sebagai media dalam memahami Al-Qur'an dan Hadis. Demikian pula ilmu nahwu disebut dengan ilmu alat karena semua ilmu agama seperti ilmu fiqih, tauhid, dan ilmu-ilmu yang berbahasa Arab akan mudah memahaminya dengan sebab ilmu nahwu.

Tujuan daripada belajar ilmu nahwu, difokuskan pada memperbaiki susunan uslub-uslub bahasa Arab yang merupakan satu kesatuan pelajaran yang terdiri atas kaidah-kaidah yang harus diajarkan dan diwajibkan bagi setiap peserta didik untuk mengetahui dan memahaminya. Serta sebagai acuan yang paling mendasar terhadap penguasaan masing-masing keterampilan bahasa dalam bahasa Arab yaitu maharat al-istima', maharat al-kalam, maharat alqira'ah, dan maharat al-kitabah.

Ilmu I'rab juga sangat penting untuk dikuasai oleh para pelajar bahasa Arab kerena fungsinya sebagai penjelas makna, oleh karena itu wajib bagi setiap orang yang hendak memahami Al-
Qur'an, Hadis dan kitab-kitab karangan Ulama agar menguasai Ilmu I'rab.

Al-Qur'an mengandung gaya bahasa yang tinggi sehingga dapat dipastikan banyak terkandung ikhtilaf i'rab didalamnya. Kita tahu bahwa masyarakat Indonesia sering membaca surat al-kahfi, yasin, waqiah, al-mulk dan sedikit mengabaikan surat-surat yang lainnya, salah satu yang perlu dibaca dan ditadabburi adalah surat Al-Insan kerena dalam surat tersebut membahas awal penciptaan manusia, jenis manusia ada yang bersyukur dan ada yang kufur sampai kepada kondisi kehidupan manusia di akhirat, kemudian surat $\mathrm{Al}$ Insan termasuk surat yang sunnah dibaca pada rakaat kedua shalat subuh pada hari jum'at sehingga alangkah baiknya menghadirkan pemahaman tentang kandungan surat Al-Insan ini kepada para pembaca agar bertambah kekhusyukan ketika melaksanakan shalat subuh.

Kemudian di antara para pelajar masih tertanam kesan bahwa bahasa Arab sangat sulit untuk dipelajari. Aspek bahasa yang dianggap paling sulit untuk dipelajari adalah aspek nahwu, tidak jarang para pelajar bahasa 
Arab merasa bosan dan kelelahan ketika mempelajari ilmu nahwu. Hal ini terjadi karena nahwu membahas kaidah atau aturan-aturan yang sangat banyak, diantaranya membahas i'rab (harakat akhir suatu kata), harakat yang muqaddarah, dan berbagai macam amil yang memiliki tugas masing-masing. Tidak dipungkiri, masih banyak kesalahan nahwiyah yang dialami para pelajar, baik pada aspek berbicara, membaca maupun menulis. Padahal mereka sudah bertahun-tahun di madrasah atau pondok pesantren. Tidak sampai di situ, para mahasiswa di perguruan tinggi pun masih banyak yang belum menguasai kaidah-kaidah nahwu tersebut.

Bahasa Arab akan terasa sulit dipahami jika tidak dipelajari dengan cara pengajaran yang benar dan tentunya menggunakan metode-metode yang tepat. Senada dengan ungkapan Ahmad Sehri Bin Punawan dalam jurnalnya, bahwa untuk memudahkan pemahaman terhadap bahasa Arab perlu pemilihan metode yang tepat dan langkah yang sesuai, sehingga pelajaran bahasa Arab yang semula terkesan sulit dipandangan para pelajar akan terasa mudah (Punawan, 2010).

Kurikulum mempunyai peran yang sangat vital dalam proses pendidikan. Kurikulum seharusnya berperan dan bersifat antisipatif dan adaptif terhadap perubahan dan kemajuan ilmu pengetahuan dan teknologi. Kurikulum dan pembelajaran merupakan dua aspek penting dalam kegiatan pendidikan. Kedua hal tersebut membahas tentang apa dan bagaimana semestinya pendidikan tersebut dilaksanakan.

Inovatif adalah sebuah kemampuan yang harus dimiliki seorang pendidik seiring banyaknya perubahan dan perkembangan kurikulum dari waktu ke waktu. Oleh karena itu seorang pendidik harus memahami perkembangan setiap kurikulum, mulai dari kurikulum 1994, disusul Kurikulum Berbasis Kompetensi (KBK), Kurikulum Tingkat Satuan Pendidikan yang disingkat KTSP serta Kurikulum 2013 (Marlina, 2013).

Upaya untuk meningkatkan kualitas pembangunan dan pendidikan di Indonesia sudah sering dilakukan oleh Kementrian Pendidikan Dasar dan 
Menengah Republik Indonesia, diantara upaya tersebut adalah dengan mengembangkan Kurikulum 2013, kurikulum tersebut telah diimplementasikan pada tahun 2013 secara bertahap di sekolah-sekolah sasaran, sehingga pada akhirnya semua sekolah menggunakan kurikulum tersebut. Kurikulum 2013 ini mulai diberlakukan pada tahun ajaran 2013-2014 dibeberapa sekolah yang sudah siap menerapkan kurikulum tersebut, akan tetapi tidak bisa dipungkiri bahwa efek dari transisi kepemimpinan pada sebuah pemerintahan bisa berpengaruh kepada suatu kurikulum, sehingga tidak heran setelah terjadi transisi kepemimpinan, Kurikulum 2013 mulai tidak diberlakukan lagi.

Kurikulum 2013 ini tidak dilaksanakan pada semua kelas mulai dari tingkat sekolah dasar sampai menegah atas, akan tetapi hanya di beberapa kelas saja, untuk tingkat dasar, baik Sekolah Dasar maupun Madrasah Ibtidaiyah hanya dilaksanakan pada kelas I dan IV saja, pada tingkat menengah baik Sekolah Menengah Pertama maupun Madrasah Tsanawiyah hanya pada kelas VII saja, dan untuk Sekolah Menengah Atas serta
Madrasah Aliyah hanya dilaksanakan pada kelas X saja (Ekawarna, 2012).

Kurikulum 2013 hadir sebagai upaya penyempurnaan dari kurikulum 2006 (KTSP) menghadirkan buku sebagai sumber belajar adalah merupakan salah satu upaya dalam mengimplementasikan Kurikulum 2013. Pada Kurikulum 2013 ini dalam mengembangkan Kompetensi Dasar (KD) tidak lagi menggunakan Standar Kompetensi (SK) sebagai bahan acuannya, akan tetapi diganti oleh Kompetensi Inti (KI) yang merupakan tingkat kemampuan yang harus dikuasai peserta didik pada setiap kelas atau program untuk mencapai standar kompetensi lulusan. Kompetensi inti memuat pengetahuan, sikap sosial, sikap spiritual dan keterampilan yang semuanya dikembangkan dalam kompetensi dasar. Diharapkan dengan upaya penyempurnaan tersebut dapat melahirkan generasi yang cerdas intelektual dan spiritual. Peningkatan ke arah yang lebih baik dalam pengamalan ajaran agama dan budi pekerti menjadi fokus utama (RI, 2016). Kreatif dan inovatif merupakan kelebihan Kurikulum 2013, hal ini dapat 
kita lihat bagaimana pendidikan karakter serta budi pekerti dapat diintegrasikan pada setiap mata pelajaran, akan tetapi tidak adanya keseimbangan antara proses pembelajaran dan hasilnya, serta kurangnya perhatian terhadap hasil ujian menjadi kekurangan dari Kurikulum 2013.

Buku Lembar Kerja Siswa (LKS) Bahasa Arab untuk Madrasah Tsanawiyah yang disediakan oleh Kementerian Agama RI dalam upaya mengimplementasikan Kurikulum 2013 memiliki kelebihan dengan pendekatan saintifiknya masih kurang pendekatan dari aspek Al-Qur'an, hampir semua materi yang disajikan tidak menyinggung ayat Al-Qur'an, khususnya dalam pembelajaran nahwu, padahal Al-Qur'an adalah objek kajian utama dari pembelajaran bahasa arab yang sangat kaya akan contoh-contoh kata maupun kalimat yang bisa dijadikan bahan pembelajaran nahwu.

Bermula dari permasalahan di atas itulah penulis bermaksud untuk penulis bermaksud untuk menulis skripsi dengan judul “Ikhtilaf Al-I'rab Dalam AlQur'an Surat Al-Insan Dan Implikasinya
Terhadap Pembelajaran Nahwu Di Madrasah Tsanawiyah".

\section{METODE}

Penulis melakukan penelitian ini dengan menggunakan pendekatan kualitatif, adapun metode penelitian yang digunakan adalah metode deskriptif analitik.

Penelitian ini digolongkan dalam jenis penelitian kualitatif karena data yang dikumpulkan berupa kata-kata yang mengandung Ikhtilaf al-I'rab dalam Al-Qur'an surat Al-Insan serta implikasinya terhadap pembelajaran nahwu di Madrasah Tsanawiyyah, yang akan dibahas dalam penelitian ini tidak berkenaan dengan angka-angka.

Analisis yang dilakukan penulis adalah berupa analisis isi (content analisis) mengenai ikhtilaf i'rab dalam surah Al-Insan. Penulis berusaha mengidentifikasi ikhtilaf i'rab yang terdapat di dalamnya serta implikasinya terhadap pembelajaran nahwu di Madrasah Tsanawiyyah.

Tujuan penelitian yaitu untuk mendeskripsikan perbedaan-perbedaan $i^{\prime} r a b$ dalam surat Al-Insan, serta mendeskripsikan implikasi perbedaanperbedaan i'rab dalam surat Al-insan 
terhadap pembelajaran Nahwu di Madrasah Tsanawiyyah.

Metode penelitian yang digunakan penulis adalah metode analisis deskriptif, sehingga tidak terikat oleh tempat tertentu.

Peneliti memulai penelitian ini pada semester genap tahun ajaran 2019/2020, Dalam jangka waktu tersebut peneliti membagi penelitian ini ke dalam beberapa tahapan yaitu tahap pengajuan proposal penelitian, pengumpulan data sampai tahap penulisan laporan.

Sumber data dalam penelitian adalah subyek dari mana data dapat diperoleh (Walidin, 2015).

Dalam penelitian ini penulis menggunakan dua sumber data yaitu Al-Qur'an surat Al-Insan dan buku ajar bahasa arab Madrasah Tsanawiyah sebagai sumber primer. Adapun sumber data sekunder, yaitu data yang dikumpulkan secara langsung oleh peneliti dan berfungsi sebagai penunjang dari sumber pertama, yaitu berupa kitab-kitab dan buku-buku yang sesuai dengan objek pembahasan, seperti kitab At Tibyan Fii I'rab Al-Qur'an karangan Abu Al-Baqa Abdullah Bin
Husein Bin Abdullah Al-Ukbari, kitab I'rabul Qur'an Wa Bayanuhu karya Muhyiddin Bin Ahmad Musthofa Darwish serta kitab-kitab/ buku-buku lainnya.

Teknik yang digunakan untuk mengumpulkan data yang berupa ikhtilaf al-i'rab pada penelitian ini adalah teknik dokumentasi. Teknik dokumentasi adalah mencari data-data berupa transkrip, buku, catatan-catatan, surat kabar, prasasti, majalah dan lain sebagainya (Arikunto, 2010).

Prosedur analisis data pada penelitian kualitatif ini dilaksanakan pada saat peneliti sebelum memasuki lapangan, selama di lapangan, dan di luar lapangan. Analisis data dilakukan secara bersama-sama dengan alur pengumpulan data. reduksi data (proses pemilihan, pemfokusan, penyederhanaan), penyajian data, penarikan kesimpulan atau verifikasi (Sujarweni, 2014).

Teknik pemeriksaan sangat diperlukan untuk menentukan keabsahan sebuah data. Pelaksanaan teknik pemeriksaan data ini berdasarkan pada beberapa kriteria tertentu, yaitu kepastian (confirmability), 
keterpercayaan (credibility), keteralihan (transferability), dan kebergantungan (dependability) (Moleong, 2017).

\section{HASIL DAN PEMBAHASAN}

Adapun hasil dan pembahasan dari proses penelitian ini adalah sebagai berikut:

\section{Hasil}

Dalam surat Al-Insan terdapat 10 kata yang terdapat ikhtilafi'rab, yaitu:

1. Kata أمشـاج pada ayat 2

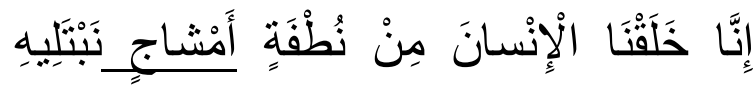

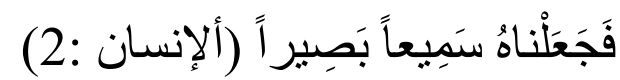

Artinya :"Sesungguhnya Kami telah menciptakan manusia dari setetes mani yang bercampur yang Kami hendak mengujinya (dengan perintah dan larangan), karena itu Kami jadikan dia mendengar dan melihat".

2. Kata عينا pada ayat 6

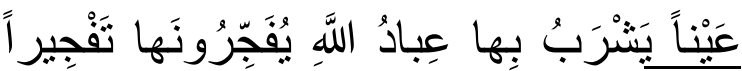

$$
\text { (الإنسان : (6) }
$$

Artinya :"Yaitu mata air (dalam surga) yang daripadanya hamba-hamba Allah minum, yang mereka dapat mengalirkannya dengan sebaik-baiknya".

3. Kata منكئين pada ayat 13

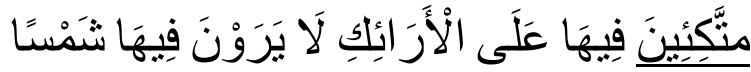

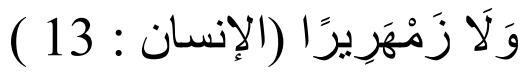

Artinya :"Di Dalamnya mereka duduk bertelekan diatas dipan, mereka tidak merasakan di dalamnya (teriknya) matahari dan tidak pula dingin yang bersangatan".

4. Kata لا يرون pada ayat 13

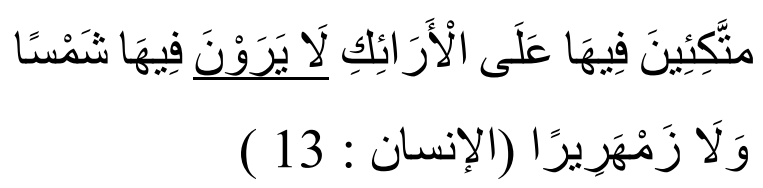

Artinya :"Di Dalamnya mereka duduk bertelekan diatas dipan, mereka tidak merasakan di dalamnya (teriknya) matahari dan tidak pula dingin yang bersangatan".

5. Kata ودانية pada ayat 14

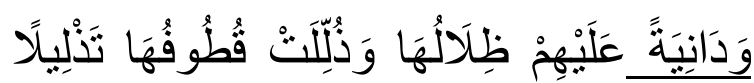

(الإنسان : (14)

Artinya :"Dan naungan (pohon-pohon surga itu) dekat di atas mereka dan buahnya dimudahkan memetiknya semudahmudahnya".

6. Kata وذذللت pada ayat 14

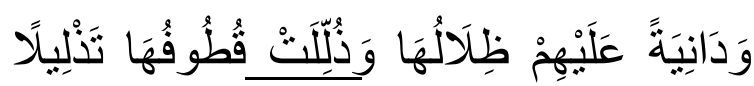

(الإنسان : (14)

Artinya :"Dan naungan (pohonpohonsurga itu) dekat diatas mereka dan buahnya dimudahkan memetiknya semudah-mudahnya". 
7. Kata 1 قو ارير pada ayat 15

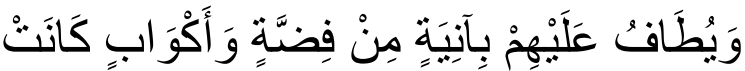

قََََاريرَاً (الإنسان : 15)

Artinya : "Dan diedarkan kepada mereka bejana-bejana dari perak dan piala-piala yang bening laksana kaca".

8. Kata قدرورهاpada ayat 16

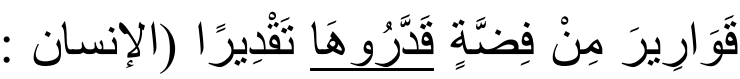

Artinya :"(yaitu) kaca-kaca (yang terbuat) dari perak yang telah diukur mereka dengan sebaik-baiknya".

9. Kata عالبهم pada ayat 21

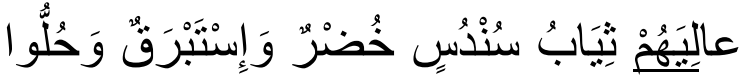

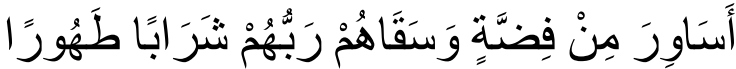<smiles>[Mg][Al]</smiles>

Artinya :"Mereka memakai pakaian sutera halus yang hijau dan sutera tebal dan dipakaikan kepada mereka gelang terbuat dari perak, dan Tuhan memberikan kepada mereka minuman yang bersih".

10. Kata استبرق pada ayat 21

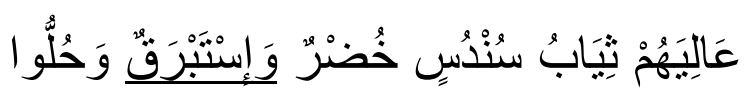

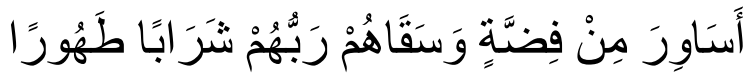<smiles>[Mg][Mg][Al]</smiles>

Artinya: "Mereka memakai pakaian sutera halus yang hijau dan sutera tebal dan dipakaikan kepada mereka gelang terbuat dari perak, dan Tuhan memberikan kepada mereka minuman yang bersih".

\section{Pembahasan}

Berikut adalah pembahasan ikhtilaf i'rab dalam surat al-insan serta implikasinya terhadap makna :

1. Kata امشاج pada ayat 2, mengandung 2 aspek perbedaan I'rab :

a. Sebagai badal dari kata نطفة

Maknanya :

Allah SWT menjelaskan hakikat dari nuthfah (air mani) bahwasanya itu adalah campuran dari air mani laki-laki dan air mani perempuan, maka nutfah tersebut tidak akan terbentuk atau tidak bisa disebut nutfah kecuali dengan bercampurnya kedua air tersebut, semua manusia diciptakan oleh Allah SWT dari nutfah kecuali Nabi Adam AS, Hawa dan Nabi Isa AS. 
b. Sebagai sifat dari kata نطفة

Maknanya :

Setelah Allah SWT mengingatkan asal dan awal penciptaanya, yakni penciptaan Nabi Adam AS dari tanah, bahwasanya sebelum ditiupkan ruh keberadaannya itu tidak disebut (tanpa nama).

Allah SWT menyifati nutfah tersebut sebagai yang bercampur, yakni campuran air mani laki-laki dan perempuan atau campuran air mani dan darah, sifat ini mengingatkan kepada manusia bahwasanya mereka itu lemah, dan di sini nampak jelas keagungan kuasanya di dalam menciptakan sehingga manusia yang beriman tunduk kepada yang menciptakannya dan menyembahnya dengan sebenarbenarnya.

2. Kata عينا pada ayat 6 , mengandung 3 aspek perbedaan I'rab :

كافور ا

Maknanya :

Sebagai badal dari كافور (kafur), dan kafur adalah wewangian yang terkenal yang keluar dari pepohonan yang tumbuh di pegunungan Cina dan India, takdir nya : يشربون من كأس (mereka minum dari gelas yang campurannya mata air) atau خمر عين يشربون خمر ا arak dari mata air arak) karena warna airnya putih menyerupai kafur, begitupun aroma dan kesejukannya. Ini adalah sebagai motivasi bagi orangorang beriman yang soleh agar senantiasa menjalankan segala perintah dari Allah SWT. Kemudian sebagai badal dari كأس gelas khusus untuk minum arak), takdirnya : يشربون من ماء عين (mereka minum dari mata air).

b. Nashab sebagai maf'ul bih dari fi'il yang dibuang, yaitu

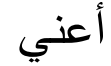
(maksud saya), yakni nashab karena ikhtisas (pengkhususan) atau dengan fi'il yang dibuang, takdirnya : بشربون (mereka meminum).

Maknanya :

Tatkala amal soleh butuh kepada kesabaran dan mujahadah, Allah SWT secara khusus menjanjikan mata air sebagai motivasi untuk istiqamah dalam amal soleh, mata air adalah menandakan bahwa air tersebut amat banyak, maka orang yang senantiasa 
puasa sunnah pada saat dahaganya mengingat mata air tersebut sehingga dia merasa bahagia, Karena demikian dia berkata : أخص عينا (saya أعني mengkhususkan mata air) atau عينا (saya maksudkan mata air), atau dengan mengingat apa yang disediakan bagi orang-orang yang beriman pada hari tersebut, maka dia berkata :
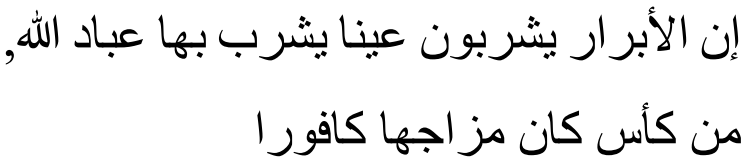

(Sesungguhnya orang-orang baik mereka minum air mata air sebagaimana hambahamba Allah juga meminum air tersebut dari gelas yang yang campurannya adalah air kafur).

c. Nashab sebagai maf'ul bih yang kedua untuk fi'il mabni majhul yang dibuang, takdirnya : أعطوا عينا (mereka diberi mata air).

Maknanya :

Dengan motivasinya Allah SWT kepada hambanya yang beriman untuk senantiasa beramal soleh bahwasanya akan diberikan pahala yang agung, maka dari situ hamba tersebut mengetahui apa yang akan diberikan kepadanya : أعطو ا عينا في الجنة تسمى (mereka diberikan mata air di surga yang bernama mata air salsabila), yakni Allah SWT mata air kepada orang-orang yang beriman.

3. Kata متكئين pada ayat 13, mengandung 2 aspek perbedaan I'rab:

a. Nashab sebagai hal dari maf'ulnya

$$
\text { جز اهم kata }
$$

Maknanya :

Allah SWT menjelaskan keadaan orang-orang beriman yang menauhidkannya dan apa yang disediakan bagi mereka sebagai balasan kesabaran mereka ketika di dunia dan ketaatan mereka kepada Allah Ta'ala. Allah SWT memotivasi mereka dengan gambaran keadaan yang akan mereka nikmati ketika di surga yaitu berupa bersandarnya mereka diatas bantalbantal dan sutera, والإتكاء maknanya adalah "posisi duduk, antara duduk biasa dan berbaring" dia menyandarkan siku dan pinggangnya dan dia memanjangkan kedua kakinya, itulah yang dimaksud duduk istirahat sebagaimana kebiasaan para raja.

b. Nashab sebagai sifat dari kata جنة 
Maknanya :

Setelah Allah SWT menjelaskan balasan bagi orang yang sabar atas ujian-ujian ketika di dunia, kemudian Allah SWT menyifati surga dengan sifat-sifat yang indah, yakni orangorang yang bertakwa didalam surga mereka bersandar pada bantal-bantal sutera.

4. Kata يرون لا لا 13 mengandung 2 aspek perbedaan I'rab:

a. Mahal nashab sebagai hal dari dhomir marfu' pada kata منكئين

\section{Maknanya :}

Setelah Allah SWT menjelaskan keadaan orang-orang beriman didalam surge mereka bersandar, beristirahat dan menikmati kenikmatan yang abadi, kemudian Allah SWT menenteramkan hati-hati orang-orang yang beriman bahwasanya barang siapa merasakan cuaca yang sangat panas ketika perang di jalan Allah dan merasakan dingin yang sangat ketika beribadah kepada Allah, maka dia tidak akan merasakannya lagi ketika di surga.

Itulah yang di maksud Allah merubahnya suatu kondisi ke kondisi yang lebih baik, itulah kehidupan orang-orang beriman ketika di surga mereka tidak merasakan lagi kesusahan-kesusahan yang mereka rasakan ketika di dunia. Takdirnya : "Orang-orang beriman menikmati kenikmatan surga dalam kondisi tidak melihat matahari dan bulan serta tidak merasakan panas dan dingin yang sangat".

b. Mahal nashab sebagai sifat dari kata

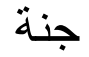

Maknanya :

Tidak dilihat didalam surga matahari dan bulan, itu adalah sifat bagi surga yang disediakan bagi orang-orang yang bertakwa, yakni sifat tersebut khusus bagi surga, sifat yg tidak dimiliki oleh tempat-tempat lain.

5. Kata ودانية pada ayat 14 mengandung 2 aspek perbedaan I'rab :

a. Nashab sebagai hal bagi kata مؤمنين لا يرون dan hal متكئين setelah hal pada ayat sebelumnya dan pada permasalahan sebelumnya.

Maknanya :

Ayat ini dan ayat sebelumnya menjelaskan keadaan orang-orang beriman di surga, Allah SWT menggambarkan keadaan-keadaan ahli 
surga sebagai motivasi bagi orangorang beriman. Huruf wawu pada pada kata ودانية menunjukkan bahwa 2 perkara (tidak adanya panas dan dingin dan mendapatkan naungan ) itu bergabung dan disediakan bagi mereka, seolah-olah dikatakan kepada mereka : "Allah memberi balasan kepada mereka dengan surga yang didalamnya berkumpul 2 perkara : menjauhnya panas dam dingin serta mendekatnya naungan kepada mereka".

b. Nashab sebagai sifat bagi kata yang dibuang dan dikira-kirakan, dan perkiraannya : وجز اهم جنة دانية

Maknanya :

Allah SWT menyifati surga dengan sifat yang indah. Allah menjelaskan bahwasanya di surga tidak ada matahari akan tetapi penduduknya butuh terhadap naungan, jika kalimat ودانية عليهر ظلالها terhadap ayat sebelumnya maka maknanya bahwasanya didalam surga ada naungan akan tetapi bukan untuk bernaung dari panas, melainkan hanya agar buah dari pohon yang menjadi naungan tersebut mendekat dan mudah dipetik.
6. Kata وذللت pada ayat 14 mengandung 2 aspek perbedaan I'rab

a. Mahal Nashab sebagai hal bagi kata<smiles>[AsH2]</smiles>

Maknanya :

Ini sebagai penyempurna dalam menjelaskan kondisi orang-orang beriman dan kenikmatan-kenikmatan yang mereka rasakan di surga, takdirnya : تدنو ظلالها عليهم مذللة لهم (naungan mendekat kepada mereka dengan kondisi tunduk kepada mereka dan mempersilahkan untuk dipetik buahnya).

b. Musta'nafah dan tidak ada tempat untuk i'rab baginya.

Maknanya :

Menjelaskan bagaimana Allah SWT memuliakan hambanya yang beriman di surga, sekiranya ada yang bertanya : "Dengan cara bagaimana orang-orang beriman mendapat kenikmatan disurga? maka jawabannya : "Dengan dimudahkannya bagi mereka memetik buah-buahan yang ada di surga, sehingga mereka dapat memetiknya baik dalam kondisi berdiri, duduk maupun berbaring". 
7. Kata قواريرا pada ayat 15 mengandung 2 aspek perbedaan I'rab

كان Nashab sebagai khobar

\section{Maknanya :}

Setelah Allah SWT menjelaskan bahwasanya orang-orang yang baik akan mendapatkan minuman yang lezat di surga, kemudian Allah SWT menjelaskan bentuk bejana-bejana yang digunakan untuk minum oleh hambahamba Allah ketika di surga, yaitu terbuat dari perak yang bening seperti kaca, perak tersebut hanya ada disurga.

b. Nashab sebagai hal, dan kata كانت كونت menjadi

Maknanya :

Setelah Allah SWT menjelaskan kenikmatan-kenikamatan surga, kemudian pada ayat ini Allah Menjelaskan tentang gelas-gelas yang terbuat dari perak yang bening seperti kaca. Jadi takdirnya (perkiraan maknanya) : diedarkan kepada mereka bejana-bejana dan gelas-gelas dari perak yang terbentuk dari unsur kaca.

8. Kata pada ayat 16 mengandung 2 aspek perbedaan I'rab: a. Mahal nashab sebagai sifat dari kata<smiles>[Mg][Mg][Mg]</smiles>

\section{Maknanya :}

Allah SWT menyifati minuman ahli surga sebagai minuman yang kadarnya sesuai keinginan mereka, tidak perlu tambahan dan pengurangan.

b. Sebagai musta'nafah dan tidak memiliki mahal I'rab

Maknanya :

Ayat ini menjadi jawaban sekiranya ada yang bertanya apakah minuman ahli surga itu banyak atau sedikit? maka jawabannya adalah minuman ahli surga itu diukur sesuai keinginan peminumnya.

9. Kata pada ayat 21, mengandung 2 aspek perbedaan I'rab yang disebabkan karena perbedaan qiraat :

a. Imam Nafi', Abu Ja'far dan Hamzah menyukunkan huruf باء dan mengasrahkan هاء, sehingga kata عebagai mubtada dan sebagai khobar.

Maknanya :

Pakaian mereka (penduduk surga) adalah sutera. 
Ikhtilaf Al-I'rab dalam Al-Qur'an Surat Al-Insan ...

b. Ulama qira'at yang lain memfathahkan ياء dan mendhomahkan هاء, sehingga kata عاليهخ sebagai dzahaf yang dimutaallakkan dengan khobar muqoddam dan kata ثياب sebagai mubtada muakhar.

Maknanya :

Pakaian-pakaian sutera ada diatas tubuh-tubuh mereka.

10. Kata خضر و إستبرق pada ayat 21 mengandung 4 aspek perbedaan I'rab yang disebabkan karena perbedaan qiraat :

a. Imam Ibnu Katsir dan Abu bakar dari Ashim membaca dengan mengkhofadkan kata خضر sebagai sifat dari kata سندس, dan merafa'kan kata إستبرق sebagai athaf dari kata ثياب.

Maknanya :

Sutera tipis yang hijau

Pakaian mereka sutera tebal.

b. Imam Abu Amr, Ibnu Amir dan Ya'qub membaca dengan merafa'kan kata خضر sebagai sifat dari kata ثياب dan mengkhafadkan kata إستبرق sebagai athaf dari kata

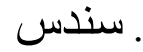

Maknanya :

Ahli surga memakai baju yang berwarna hijau, dan begitupun mereka memakai sutera yang tebal dan yang tipis.

c. Imam Nafi dan Hafs dari Ashim خضر و إستبرق membaca kata dengan cara merafa'kannya, sehingga kata خضر sebagai sifat dari kata ثياب dan kata إستبرق sebagai athaf dari kata خضر

Maknanya :

Ahli surga memakai baju yang berwarna hijau dan memakai baju sutera yang tebal.

d. Imam Hamzah dan Kisai membaca kata dengan cara mengkhafadkannya, sehingga kata سندس sebagai sifat dari kata خضر dan kata إستبرقdi athafkan pada

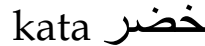

Maknanya : 
Ahli surga memakai baju sutera tipis yang berwarna hijau dan memakai sutera tebal.

\section{Metode Identifikasi I'rab}

Metode identifikasi I'rab yang digunakan oleh para ahli bahasa adalah metode tahlili, yaitu menganalisis mulai dari huruf per huruf, kata per kata hingga kalimat per kalimat.

Pada awalnya biasanya ulama akan mengklasifikasikan terlebih dahulu apakah kata yang akan di I'rab itu termasuk isim, fi'il atau huruf.

Jika kata itu termasuk kalimah isim maka disebutkan terlebih dahulu jabatan katanya (fail, maf'ul dan sebagainya), kemudian sebutkan i'rabnya (rofa, nashab atau jar), kemudian sebutkan ciri atau alamat i'rabnya dan terakhir sebutkan sebab ciri i'rabnya.

Jika kata itu termasuk kalimah fi'il maka yang pertama kita sebutkan jenis fi'ilnya (madhi, mudhari atau amr), kemudian sebutkan i'rabnya (rafa, nashab atau jazm) ini khusus pada fi'il mudhori, karena fi'il madhi dan fi'il amr itu bersifat mabni (tidak ber i'rob), fi'il madhi mabni fathah sedangkan fi'il amr mabni sukun/jazm, kemudian sebutkan ciri i'robnya, dan terakhir sebutkan sebab ciri i'rabnya.

Jika kata itu termasuk kalimah harf , maka kita cukup menyebutkan jenis harf tersebut dan mabni terhadap harakat apa (lihat harokat akhir).

Contohnya pada surat Al-Insan : 5 berikut ini :

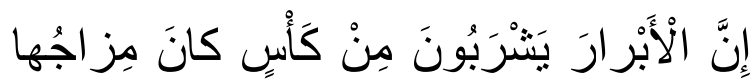
كافُوراً

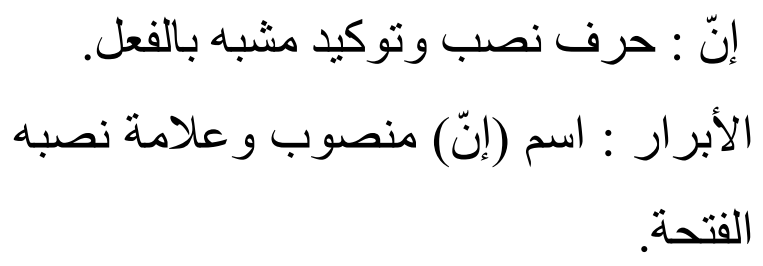

يشربون : الجملة الفعلية في محل رفع خبر (إنّ) و هي فعل مضار ع مرفوع بثبوت النون , والواو ضمير متصل في محل رفع فاعل. من كأس : جار ومجرور متعلق بشربون, و (من) حرف جر لابتداء الغاية أي من خمر. كان مز اجها كافور ا : الجملة الفعلية في محل جر صفة/نعت لكأس . كان : فعل ماض ناقص مبني على الفتح ـ مز اج : اسم كان مرفوع بالضمة . و (ها) ضمير منصل مبني على السكون في محل جر بالإضافة . كافورا : خبر كان منصوب بالفتحة(Shalih, 1993). Implikasi Ikhtilaf i'rab dalam Pembelajaran Nahwu 
Keberadaan ikhtilaf i'rab dalam bahasa Arab ini dapat dijadikan bahan pembelajaran nahwu yang efektif di Madrasah Tsanawiyah, karena dengan hanya menghadirkan satu contoh kalimat bahasa Arab yang mengandung ikhtilaf i'rab didalamnya bisa digunakan untuk menjelaskan dua, tiga atau lebih judul pembahasan ilmu nahwu, seperti kata pada ayat ke-2 surat Al-Insan yang mengandung 2 aspek perbedaan I'rab yaitu bisa sebagai sifat dan bisa juga sebagai badal, sehingga dengan demikian itu lebih efisien untuk dihafal, me-review setiap materi yang saling berkaitan dan sangat membantu dalam mengasah ketajaman analisis kaidah nahwu siswa terhadap kalimat-kalimat bahasa Arab.

Pembelajaran yang penulis maksud adalah bagaimana metode yang dapat diaplikasikan oleh seorang guru bahasa Arab dalam mengajarkan ilmu nahwu dengan menggunakan ayat-ayat pada surat Al-Insan sebagai objek kajian maupun contoh materi.

Adapun cara pembelajarannya adalah menggunakan metode istiqraiyah dan qiyasiyah dengan menghadirkan surat Al-Insan sebagai contoh dalam pembahasan materi.

Metode Istiqraiyah atau Istinbathiyah disebut pula metode induktif, yaitu suatu metode yang dilakukan dengan cara pemaparan contoh-contoh terlebih dahulu, kemudian memaparkan kaidah-kaidah nahwu secara umum.

Kelebihan metode istigraiyah ini yaitu dapat memberikan peluang bagi seorang guru bahasa arab untuk memilih contoh-contoh secara leluasa, selain itu metode ini juga dapat membantu guru serta para pelajar dalam mempercepat proses belajarnya. Metode ini juga dipandang sebagai metode yang mudah digunakan sehingga sangat membantu dalam pembelajaran nahwu, dimana seorang pelajar akan benar-benar memahami kaidah.

Adapun Penerapan metode induktif dalam pembelajaran di kelas antara lain sebagai berikut:

a. Guru menghadirkan contohcontoh kata maupun kalimatkalimat sebagai objek kajian nahwu

b. Guru menjelaskan kaidah-kaidah nahwiyah yang terdapat pada contoh 
c. Guru bersama siswa menyimpulkan kaidah-kaidah nahwu apa saja yang terdapat pada contoh.

d. Guru memerintahkan siswa untuk mengerjakan latihan-latihan.

Adapun metode qiyasiyyah adalah cara mengajarkan nahwu dengan cara memaparkan kaidah-kaidah nahwiyah terlebih dahulu terlebih dahulu, kemudian memberikan contoh-contoh untuk mengaplikasikan kaidah-kaidah nahwiyah tersebut.

Adapun penerapan atau bentuk pengaplikasian metode qiyasi ini adalah sebagai berikut:

a. Pelajaran dimulai oleh guru dengan mengutarakan tema tertentu.

b. Menjelaskan kaidah-kaidah nahwu

c. Siswa diminta untuk memahami dan menghafal kaidah-kaidah nahwu.

d. Mempresentasikan contoh-contoh yang sesuai dengan kaidah-kaidah nahwu.

e. Menyimpulkan materi pelajaran yang sedang berlangsung

f. Guru meminta siswa untuk mengerjakan soal-soal latihan.

\section{SIMPULAN}

Berdasarkan hasil analisis ikhtilaf $i^{\prime} r a b$ pada surat Al-Insan ayat 1 sampai 31, maka dapat disimpulkan sebagai berikut :

1. Kata yang memiliki ikhtilaf i'rab dalam surah Al-Insan ini berjumlah 10 kata.

2. Kata أَمْثناجٍ pada ayat 2 memiliki dua aspek perbedaan, yaitu sebagai badal dan sifat.

3. Kata عَنْili pada ayat 6 memiliki dua aspek perbedaan, yaitu sebagai maf'ul bih dan badal.

4. Kata منَّكئينَ pada ayat 13 memiliki dua aspek perbedaan, yaitu sebagai hal dan sifat.

5. Kata لَ لَرَوْنَ dua aspek perbedaan, yaitu sebagai hal dan sifat.

6. Kata وَدَانِيَنَ pada ayat 14 memiliki dua aspek perbedaan, yaitu sebagai hal dan sifat.

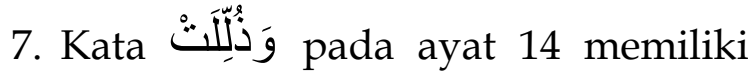
dua aspek perbedaan, yaitu sebagai hal dan musta'nafah. 
8. Kata قَََارِيرَ pada ayat 15 memiliki dua aspek perbedaan, yaitu sebagai khobar كَانَ dan hal.

9. Kata قََََُّو هَا pada ayat 16 memiliki dua aspek perbedaan. Yaitu sebagai hal dan musta'nafah.

10. Kata عَالَلِهُهُ pada ayat 21 memiliki dua aspek perbedaan, yaitu sebagai mubtada berdasarkan qiraat Imam Nafi', Abu Ja'far dan Hamzah dan dzharaf berdasarkan qiraat ulama lainnya

11. Kata وَإِنْنَبْرَقْقُ 21 memiliki empat aspek perbedaan, yaitu sebagai athaf berdasarkan qiraat Imam Ibnu Katsir, Abu Bakar dari Ashim, sebagai sifat berdasarkan qiraat Abu Amr, Ibnu Amir dan Ya'qub, sebagai athaf berdasarkan qiraat Imam Nafi dan Hafs dari Ashim dan sebagai athaf berdasarkan qiraat Imam Hamzah dan Kisai

Adapun Metode Pembelajaran Nahwu adalah sebagai berikut :

a. Metode Qiyasiyyah

(Deduktif/analogi)

Metode ini adalah metode dengan cara memaparkan kaidah terlebih dahulu kemudian contoh. Dalam metode ini menitikberatkan pada pemaparan kaidah, siswa yang harus menghafal kaidah dan pemberian contoh yang berfungsi memperjelas dan menerapkan kaidah tersebut.

b. Metode Istigraiyyah

(Induktif/istinbath)

Metode ini diterapkan dengan cara mengemukakan contoh-contoh terlebih dahulu kemudian menjelaskan kaidahkaidahnya.

\section{DAFTAR PUSTAKA}

Agustina, A. C. (2009). Pengajaran Kompetensi Bahasa. Angkasa.

Al-Ghalayini, S. M. (2010). Jami' AdDurus Al-'Arabiyyah. Dar At-Taufiq Li At-Turats.

An'im, A. (2016). Sang Pangeran Nahwu Al-Ajurumiyyah. Mu'jizat Group.

Arikunto, S. (2010). Penelitian Suatu Pendekatan Praktik. Rineka Cipta.

Dahlan, S. A. (2015). Mukhtasor Jiddan. Haramain.

Ekawarna. (2012). Pemahaman Guru SD tentang Implementasi K-13 di Provinsi Jambi. Jurnal Cerdas Sifa Pendidikan, 1(2).

Hamid, B. M. (2012). Metode dan Strategi Pembelajaran Bahasa Arab. UIN Maliki Press.

Khaldun, A. (2006). Muqaddimah Ibnu Khaldun. Daar Kitab al-Ilmiyyah.

Marlina, M. E. (2013). Kurikulum 2013 yang Berkarakter. JUPIIS: Jurnal Pendidikan Ilmu-Ilmu Sosial., 5(2).

Moleong, L. J. (2017). Metodologi Penelitian Kualitatif. Remaja Rosdakarya. 
p-ISSN 2721-155X | e-ISSN 2721-5121

DOI: $10.30997 /$ tjpba.v2i1.3630

Punawan, A. S. (2010). Metode Penelitian. Pustaka Baru Press.

Pengajaran Nahwu Dalam

Pengajaran Bahasa Arab. Jurnal Hunafa, 7(1).

RI, K. A. (2016). Bahasa Arab Untuk Madrasah Tsanawiyah Kelas IX. Kementerian Agama Republik Indonesia.

Shalih, B. A. (1993). Al-I'rab Al-Mufasshal Li kitabillahi Al-Murattal. Daar AlFikr.

Sujarweni, V. (2014). Metodologi 